Illinois State University

ISU ReD: Research and eData

Theses and Dissertations

3-24-2015

\title{
The Quiet Girl In The Quiet Room: Can The Subaltern Speak?
}

Julie Tran

Illinois State University, jbtran92@gmail.com

Follow this and additional works at: https://ir.library.illinoisstate.edu/etd

Part of the Asian American Studies Commons

\section{Recommended Citation}

Tran, Julie, "The Quiet Girl In The Quiet Room: Can The Subaltern Speak?" (2015). Theses and Dissertations. 379.

https://ir.library.illinoisstate.edu/etd/379

This Thesis is brought to you for free and open access by ISU ReD: Research and eData. It has been accepted for inclusion in Theses and Dissertations by an authorized administrator of ISU ReD: Research and eData. For more information, please contact ISUReD@ilstu.edu. 


\title{
THE QUIET GIRL IN THE QUIET ROOM:
}

\section{CAN THE SUBALTERN}

\section{SPEAK?}

\author{
Julie Tran
}

\section{Pages}

May 2015

I was searching for a cure for being voiceless when I learned that I am not voiceless at all; I am silent. Voice, however, is a product of the dominant ideology of the ruling class, a product equated with presence and participation, whereas silence is a product of the resistance of the subaltern, a product equated with self-effacement and submissiveness. Therefore, voice is often understood as the opposite of silence, and those who possess voice possess power. The subaltern is consequently excluded, only heard and considered when adopting Western language and culture. This conformity fractures the identity of the subaltern, erasing fragments of the truth. Still, alienated within the Western culture, the subaltern is disconnected, dissociated, and does not belong: these are the meanings of the word "foreign." Experiences of racial and domestic violence born of coerced migration and assimilation reduce the subaltern to a state of destability, facing the impossibility of feeling physically or mentally connected. As long as the ruling class equates voice with presence and participation and silence with selfeffacement and submissiveness, the voice, the silence of the subaltern will be silenced forever. Here, I attempt to attain voice, and "self," on the page. 
THE QUIET GIRL IN THE QUIET ROOM:

CAN THE SUBALTERN

SPEAK?

JULIE TRAN

A Thesis Submitted in Partial Fulfillment of the Requirements for the Degree of MASTER OF ARTS

Department of English

ILLINOIS STATE UNIVERSITY 
Copyright 2015 Julie Tran 
THE QUIET GIRL IN THE QUIET ROOM:

\section{CAN THE SUBALTERN}

SPEAK?

JULIE TRAN

COMMITTEE MEMBERS:

Kass Fleisher, Chair

Ricardo Cortez Cruz

Rebecca Saunders 


\section{CONTENTS}

CONTENTS

CHAPTER

I. CRITICAL PREFACE 1

II. SNAKE GIRL 11

III. THE QUIET ROOM $\quad 14$

IV. INCUBATORS 33

V. WHEN NOTHING HAPPENED 36

VI. EVACUATION 44

VII. CHASING SHADOWS 45

$\begin{array}{ll}\text { VIII. CITIZENSHIP } & 54\end{array}$

IX. LIVING WITH DYING FROM

$\begin{array}{lll}\text { X. TOO AMERICAN } & 72\end{array}$

$\begin{array}{ll}\text { REFERENCES } & 74\end{array}$ 


\section{CHAPTER I}

\section{CRITICAL PREFACE}

I was searching for a cure for being voiceless when I learned that I am not voiceless at all; I am silent. Voice, however, is a product of the dominant ideology of the ruling class, a product equated with presence and participation, whereas silence is a product of the resistance of the subaltern, a product equated with self-effacement and submissiveness. Therefore, voice is often understood as the opposite of silence, and those who possess voice possess power. The subaltern is consequently excluded, only heard and considered when adopting Western language and culture. This conformity fractures the identity of the subaltern, erasing fragments of the truth. Still, alienated within the Western culture, the subaltern is disconnected, dissociated, and does not belong: these are the meanings of the word "foreign." Experiences of racial and domestic violence born of coerced migration and assimilation reduce the subaltern to a state of destability, facing the impossibility of feeling physically or mentally connected.

As this is a work of creative nonfiction, my thesis is inspired by my own experiences. I am writing through the lens of an American child of Vietnamese immigrants. Margaret Cho, a Korean-American comedian, speaks the truth of Asian experiences: "It's hard when you're a child of immigrants. You spend half your day in America and the rest of your day in a foreign land." While I was raised by Vietnamese immigrants, I have never been able to claim to be Vietnamese for any reason other than 
the color of my skin, which is what prompts people to ask me, "What are you?" I must tell them that I am Vietnamese, only to be asked follow-up questions about the Vietnamese language and culture. My American questioners then find me silent, since I do not know the answers to their (exotic) questions. Simultaneously, while I was born in the United States and grew up here, I have never been able to claim to be American for any reason other than the country I inhabit. Even when I try to claim to be American, my American questioners insist, "But what are you?" I am accepted, then, neither as Vietnamese nor American; thus, America is as foreign to me as Vietnam.

I violate conventions of both cultures at once. While my Vietnamese parents taught me at home that a girl must never speak unless spoken to, and a child must never ask an elder a question, since it would imply disrespect for that elder, my American teachers failed me at school for adhering to Vietnamese convention in class, particularly when I "respected" the instructor by not debating her. Throughout my years in academic institutions, some teachers assumed that I have a speech disorder; some granted me permission to be silent; and others explained that if they allow me to be silent, I would be the recipient of "special treatment," and every student should be assessed "equally."

Since silence is sometimes pathologized in U.S. culture, I was at times subjected to Western mental health practitioners. American doctors grew impatient when I did not speak about symptoms, or spoke at a low volume; some asked if I had an intellectual disability. When I spent some time in a mental institution for adolescents, my American therapists scolded me for not speaking and punished me when I did speak. I soon learned that success in this context was not about the act of speaking, or even about the volume of speaking; it was all about providing the language my listeners wanted to hear. When I 
had to speak to mental health professionals, I had to speak the language of contentment. My American therapists did not want me to speak about myself; they wanted me to tell them I was happy. It did not seem to matter whether or not I was mentally healthy or actually happy; what seemed to matter most was that I spoke the words. I began to see that the language of contentment was not the language of the truth.

I began to write down experiences as they happened and as I relived them. Sometimes, I would describe images; other times, I would record dialogues. My desire to understand and remember my experiences grew into obsession. It became frustrating as I held onto words, pages, and fragments that I felt contained no purpose. I did not know what was at stake or what I wanted my writing to do. Throughout writing this thesis, I began learning that this project is about putting language to the truth.

As the characters are based on people in my life, my thesis exemplifies the effects of coerced migration, coerced assimilation, and coerced happiness; it exemplifies the fractured identity of the subaltern that comes from conformity as a means to survive while still being alienated within the adopted culture. These characters struggle to maintain stability without an asserted identity. Because the narrator finds that the page makes for a convenient containment of her voice, she chooses to write more than she speaks. However, professionals in both academic and mental institutions insist on hearing her voice in oral speech—with all the aforementioned assumptions still intact. She encounters people who do not want to hear her voice at all, and prefer that she exists according to the model minority stereotype, being the quiet, composed, submissive, selfeffaced (but high-functioning) Asian female they expect her to be. I wanted to write an 
account that both invites readers to examine this problem and succeeds as establishing a (contained, printed) voice for the subaltern.

This thesis contains two parallel narratives. The first narrative tells the story of a character's life in Vietnam during the war, leading to migration. The second narrative tells the story of life in America, post-migration, as experienced through the aforementioned character's daughter. The two narratives are weaved together, leading readers to follow the thread of compelled migration and assimilation. Therefore, these stories are told simultaneously instead of chronologically, emphasizing the inevitable effects of the past on the present. The first narrative, "Snake Girl," begins after the Vietnam War has already begun. The title character's name is given to her by her parents when she is born in Quang Tri so that she would know the year of her birth in case anything was to happen. Unable to provide for her after their parents die, her sister sends her to Saigon to become a servant to a family, and in return, have a place to live and food to eat. The family she works for abuses her and breaks her spirit. When they send her on an errand after another night of punishment, she decides to run away. This is where the story begins. Snake Girl wanders through the city until she meets a kind woman who decides to raise her. I did not want "Snake Girl" to focus on the politics of the U.S.Vietnam conflict per se. The focus is on the children of the war and their children, and the attendant destabilization.

In the third narrative, "Incubators," about a decade has passed since Snake Girl goes to live with the woman. The war is ending. Snake Girl has two children fathered by different men. She has hope that the father of her second child will soon make her his wife and become a father to her children. Instead, she finds that he has fathered another 
child and wants her to raise that child, as well, since its mother died in childbirth.

Though she tries, Snake Girl finds that she cannot raise a child that is not hers. I wanted "Incubators" to show how children of the war are abandoned, followed by the fifth and sixth narratives, "Evacuation" and "Chasing Shadows," which explain that Snake Girl's firstborn son, Peter, was fathered by a black U.S. soldier, making him a mixed-race Amerasian. For these reasons, Peter is despised by his own stepfather, creating a cycle of racial and domestic abuse. However, Peter's Amerasian status makes it possible for Snake Girl and her children to leave Vietnam for America.

The accounts of their lives in America are told through the narration of Snake Girl's youngest child, who is born in the United States, making that child a natural-born citizen. The second, fourth, and seventh narratives, "The Quiet Room," "When Nothing Happened," and "Citizenship," give voice, on the page, to the violence that these characters endure. Alienated within the country they now inhabit and where, ironically, they now possess citizenship (a sort of belongingness), these characters nevertheless lack agency within the context of U.S. racism. The narrator learns how to respond to violence with silence. In "Living With Dying From," readers are offered glimpses into her psyche. This narrative is written mostly in monologues and dialogues with little narration to exemplify disorganized thoughts and feelings of someone who is disconnected and dissociated. There is a vague timeline as the piece offers years in which these monologues and dialogues take place, but it is not chronological in order to show the disorganized thought process of the narrator as she relives the past in the present. For someone of her status, with little sense of self, and with "self" (in relation to others) an impossible attainment, the past and present cannot be separated. 
In "Too American," the narrator has a conversation with her father in which he tells her that she is becoming too American. Later, she encounters a stranger who wants to know about her ethnic background. As a natural-born American citizen who is disconnected from the Vietnamese language and culture, the narrator answers that she is actually an American. Her answer, however, is rejected. She then informs him that her parents are from Vietnam, but any statement she makes with regard to nationality are contradicted, for a U.S. audience, by the presumed evidence provided by her body — her appearance. With "Too American," I wanted to show that though the narrator is bicultural, she is also no-cultural.

On the concept of becoming foreign, Margot Badran writes: In my twenties, when I went to live in Egypt, I suddenly became a foreigner. Foreigners were persons who found themselves in countries other than their own, other than the country of their birth or citizenship, and so this status was laid upon me. But to myself I was never a foreigner. The me is not foreign, so I thought. Of course, I was well aware that when outside one's own country one is foreign and that, while not foreign to myself, I was foreign to others. And so, I wore foreignness like a new coat—one that did not quite fit and was often eyed oddly. As foreignness was bestowed upon me, so was this foreignness gendered. My status as a female foreigner was thickened and further mediated by my marriage to an Egyptian and by my intent to settle in Egypt. I became the foreigner within. (qtd. in The Concept of the Foreign 93).

Citizenship of an immigrant, and natural-born citizenship of an immigrant's child, does not provide the same proprietary status afforded someone from the dominant culture and 
race. Even after adopting the culture, the foreigner is still seen as a foreigner. The subaltern cannot belong.

In her work, Schizophrene, Bhanu Kapil writes on the intersection of immigrant experience and mental illness, returning us to a focus on language that represents this lack of belonging for the subaltern. She writes:

Immigrant. Nothing happens. Immigrant.

Below the aeroplane is the river.

Someone who could weight me down, whether physically or with language, in all the ports of call: Athens in January, Munich in February, London in March! Immigrant, there's nothing erotic about the ten rupees in your pocket. The account begins mid-ocean, where even your boarding pass is knotted in a handkerchief in your broken-down suitcase in the hold. Dazzling you, I select your suitcase. You watch it float over the railing and into the air. Yellow lightning in the silver sky, and the three sheets of rain, so bamboo, so cream. Stupid man, you watch your suitcase sink, burning up its requisite energy simply by breathing. Everything breathes, even you. Breathe, immigrant. Fly, immigrant. Sail, immigrant. Blue. (Schizophrene 2).

Kapil illuminates how a word such as "immigrant" can redefine a person. First, it defines someone legally and politically. Since they have left their presumably native country, they have sacrificed a former sense of belonging, and are now considered "foreign" to their native cohorts. Labeled "immigrant" by the country they have migrated to, they are 
branded as alien again. Kapil brings our attention to the word by repeating it, and even italicizing it. Lisa Lowe explains:

In the last century and a half, the American citizen has been defined over against the Asian immigrant, legally, economically, and culturally. These definitions have cast Asian immigrants both as person and populations to be integrated into the national political sphere and as the contradictory, confusing, unintelligible elements to be marginalized and returned to their alien origins. (4) Kapil writes, "Everything breathes, even you." The (new) dominant culture acknowledges that immigrants breathe, but this does not mean that citizens equate them to a living, breathing human. They actually mean to claim that breathing doesn't mean anything, demonstrating how the dominant culture can find any way to lessen the value of the life of an immigrant. From the dominant culture's perspective, immigrants may breathe like citizens, but they are not like them because everything breathes. Humanity is not an inclusive concept. With the usage of the word "you" and the phrases "even you," and "you immigrant," Kapil sets up a split for us to witness: a "me" versus "you" dichotomy. She writes, "Someone who could weight me down, whether physically or with language," emphasizing the power of language when deployed by someone from the dominant culture. On language, Erica Hunt writes:

Dominant modes of discourse, the language of ordinary life or of rationality, of moral management, of the science of the state, the hectoring threats of the press and media, use convention and label to bind and organize us.

The convenience of these labels serves social control. The languages used to preserve domination are complex and sometimes contradictory. Much of how 
they operate to anesthetize desire and resistance is invisible; they are wedded to our common sense; they are formulaic without being intrusive, entirely natural no marks on the body at all.

These languages contain us, and we are simultaneously bearers of the codes of containment. (qtd. in Bernstein 199-200).

Hunt makes us consider the truth behind such dominant modes of discourse, suggesting that it is used to serve social control. She warns that it contains us and we are actually the bearers of the codes of containment. Kapil gives us an example of this with the word "immigrant." It is not simply about the usage of the word, but about the way the word is stamped upon a human. "Immigrant," as a word used by society and rationalized by the nation, contains hidden violence as it serves social control and ensures that the hegemonic power - particularly the exclusive power of the border—is not threatened.

"More than simply a trope, then," Patti Duncan writes, "silence for marginalized groups of people in the United States and elsewhere is also a history, a reality, and a lived experience. Silencing is a means of domination, and access to free speech is often limited. Control of language is a constant and powerful tool in the acts of domination and colonization" (15). But silence is a voice; it is a response. It can be a tool of resistance.

For the narrator in my thesis, silence is her voice. In most instances, silence is her response to violence. She grows up in a house full of secrets, constantly reminded that she must not speak the truth, or that she must not speak at all. She is forbidden at home to talk about what she remembers. She is scolded for not speaking up in her American schools. There are multiple circumstances when she tells readers what she wants to ask 
and what she wants to know, but in reality, she continues to speak silence. At times, she makes compromises and breaks her silence to speak the words that are demanded from her by those in power around her. This weakens her true voice and further erases parts of her identity and the truth she is trying to tell. Silence is one way of reasserting her identity, her sense of "self." But as long as the ruling class equates voice with presence and participation and silence with self-effacement and submissiveness, the voice, the silence of the subaltern will be silenced forever. Here, I attempt to attain voice, and "self," on the page. 


\section{CHAPTER II}

\section{SNAKE GIRL}

Snake Girl's skin was still tender from last night's thrashing. She stepped down the streets, softly whimpering, holding her arms as if they would fall off if she let go. Gripping nails broke skin.

"Dad, Mom, where are you," she sobbed to herself. "Why did you leave me behind? Please come back and take me. Where did you go? I want to go with you." Her feet carried her to the cart where the elderly woman who sold fish sauce.

"A small bowl of sauce, is that right?"

Snake Girl stared back at the woman, teary-eyed.

"If you're not buying anything today, step away, little girl. You're going to scare away my customers, then how will I eat tonight?”

Her hand trembled as she pulled out the money Master had slid into her pants in the morning. Her eyes moved to the sun's position and she knew it was too late. Even if she got back now, she would pay for it in blood.

So she walked away.

She walked away from the thrashes, she walked away from the scorns, she walked away from the last connection she had to her blood.

Her master's money took her to a neighborhood she had only heard about in strangers' stories. It was the heart of the city, the busiest place she had ever seen. She 
strolled by the different carts of food breathing in the aromas of dishes she'd only dreamed about. She rubbed her stomach then searched for a place to rest her legs.

She sat down in the driest spot she could find and watched the rats scurry away. Her eyelids began to fall when she felt the coolness of a shadow over her.

"Where's your mom, child?" the woman asked.

"Lost."

"Where do you live?"

"Nowhere."

"How old are you?"

“Ten."

"Are you hungry?"

Snake Girl's stomach twisted around inside of her.

"Come with me. I have a little rice left."

She swallowed the rice in clumps while the woman watched.

"What's your name?"

"Snake Girl."

"You were born the year it began. They never gave you a real name?"

Snake Girl sat picking her teeth with her fingers staring back the woman.

"They probably didn't think you would make it." She focused her eyes and looked more closely, more pitifully at the child before her. "Or did they know they wouldn't make it?"

Snake Girl picked up the bowl to lick clean.

"Do you even know where you were born?" 
"Quang Tri."

"Then how did you get to Saigon?"

"My sister took me here to work. She gave me to the family she worked for when she was small like me. But they, but she--"

Her voice shook when the woman took her hand.

"That's your past now." 


\section{CHAPTER III \\ THE QUIET ROOM}

Suicide is wrong.

By law.

\section{By religion.}

By morality.

Because it is wrong to want to die.

I go to my locker to drop off my backpack before heading outside for recess. I see the social worker make his way up the stairs. He smiles at me. Something is not right. He turns to whisper to my math teacher. I turn to walk away when she blocks me. My friends are waiting and she tells them to leave.

"We want to talk to you downstairs, Julie." He smiles again.

"I don't want to. I have to go now." I mumble as I try to make my way past Mrs. Learnahan's arms.

She grabs my hand. "No, Julie, you have to go with Mr. Parker. Julie, he told me- he told me that you hurt yourself." 
I pull my hand back. She grabs both of my hands now. I look at her face and I see her start to cry.

"We want to help you, okay?" she tells me through sobs. "Please, Julie, I don't want you to kill yourself. Just let us help you." She cries as she hugs me.

I don't understand why she's crying. I don't understand why she's repeating my name.

When we go downstairs to the counselor's office, they tell me to have a seat. The counselor is on the phone describing my cuts.

They won't tell me what's happening.

I hear sirens. I know they're here for me. From the window, I watch two paramedics bring a stretcher into the school. I get up to pace around the room. I stop at the bookshelf and run my fingers across each book. I pull out a random one with a big, yellow duck on the cover.

The social worker walks over to me and smiles at the cover. "Was that a happier time for you?"

"No." I put the thing back.

I wish he would stop trying so hard. I wish he would stop asking me questions. I wish he would stop watching me. I wish he would stop smiling.

One of the paramedics walks over to me. "Are you ready?"

I look down at the floor. "Where am I going?"

"We're here to take you to the hospital."

"What for?"

"We're going to help you." 
“Can you help me?” I look at him now.

He doesn't answer my question, and leads me over to the stretcher.

"I can walk," I say.

"It's a safety thing. If something happens while you walk to the ambulance, we'll get in trouble."

They put me in the stretcher. They put me in the ambulance.

"Your family's here," Mr. Parker tells me before they close the doors. They're going to follow the ambulance and meet you at the hospital."

The paramedics turn on the sirens as they start driving. I don't see the point. It's not an emergency. I see my brother's car. My mom is in the passenger's side and she's crying. I can't hear her.

But I can.

I start to cry. I can't turn my body, so I turn my head to the side so I don't have to see her anymore.

"Why are you here?" the nurse asks me as they admit me.

I look down.

"Come on, Julie, tell us why you're here."

I am still. 
He moves to make some marks on his clipboard. When he finishes, I can feel his eyes on me, giving me one last chance to explain myself.

I don't move.

He leaves and my sister, Melanie, comes into the room.

"Look at me, Julie," she says gently.

I don't.

“Okay. Then listen. The hours in here are very, very long. Trust me. I've been in one of these places, too. Do you remember?"

I look at her.

I do remember.

"Can you please change your mind and just come home with us? Whatever it is, we can fix it. You can still change your mind before it's too late. Once they finish the paperwork, they can keep you for as long as they want, Julie."

I remember it all.

I bite my lip to keep from crying.

She lets out a sigh and leaves, too.

A different nurse comes into the room. She starts talking to me, but I just stare at her. I remember the first day of fourth grade, and the name tags on the desks that say I get to sit next to Joanna. We sit down and talk about our summers. Then our teacher walks over and stands right next to me.

I stop talking.

"I'm your teacher, Ms. Prasko," she says in a sugary sweet voice. "I see you two talking a lot. Are you best friends?" She looks at me to answer. 
I just stare back. I sit up straight, eyes still on her, mouth closed.

She's smiling, waiting. “Are you?" she asks again.

I don't say a single word. I don't even flinch.

She stops smiling. "I'm sorry, honey, do you not understand? Do you not speak English?"

Joanna laughs. "She doesn't talk to grownups."

"Oh.” Ms. Prasko sounds disappointed and confused. She walks away and moves

on.

The final grades on my report card for that school year:

$\begin{array}{lr}\text { Mathematics } & \text { A } \\ \text { Sciences } & \text { A } \\ \text { Social Sciences } & \text { A } \\ \text { Library Sciences } & \text { A } \\ \text { Language Arts } & \text { A } \\ \text { Physical Education } & \text { A } \\ \text { Health } & \text { A } \\ \text { Computer } & \text { A } \\ \text { Writing } & \text { A } \\ \text { Listening } & \text { A } \\ \text { Speaking } & \text { F }\end{array}$

When my mom and I go to pick up my report card, Ms. Prasko explains all of my grades to her, doing all of the talking. Then she goes on and on about how she doesn't know why I won't speak up in class. My mom is nodding her head to show she 
understands what she's saying. She's nodding her head so much, I'm thinking it might fall off of her neck. She doesn't say a single word.

We step out of the classroom and she starts yelling at me in Vietnamese, telling me if I don't speak up, if I don't talk, people are going to think I'm stupid.

She keeps asking, "Do you want to be stupid? Do you want to be illiterate like me? Do you want to be a failure? Do you want to work in a factory forever for minimum wage?"

I just nod my head to show I'm listening.

She snaps. "You look stupid when you nod your head. Talk. Talk so people know you know something."

"I understand."

The nurse takes a picture of me and the flash makes me see spots.

"It's for your file," she explains.

Another nurse comes to walk me upstairs. I am a prisoner and she is a guard. She tells me I have to shower. She takes me to the showers, but she doesn't leave. I undress and step behind the curtain. The water is just starting to soak my hair when she says I have to hurry because she doesn't have all night. I step out and she's going through my clothes.

"You can't keep your belt. And you can't keep your bra."

"Why not?"

"Because you can use them to kill yourself." 
She gives me back my jeans and turtleneck and tells me I can put them away in the dresser in my room. A room with a dresser. Maybe I can pretend I'm on vacation, staying at a hotel.

She hands me some hospital clothes. I put them on and tell her I need a tampon. She walks me over to the nurse's station and they give me one. Then she walks me to my room. I feel at home for just a second when I see the streetlights come in through the window. A window. But then I see that it has bars. I can't keep my belt or bra, so of course the window has bars.

The walls are the ugliest shade of purple. The bed and dresser are made from cheap, rotting wood. And they are nailed to the floor. How am I going to kill myself that way? Rearrange the room to death? There's a bathroom with just a toilet that connects my room to the next and neither door has a lock.

"That's your roommate already asleep," the nurse gestures to the body on the other bed. "Wake up call is at six." She leaves and locks the door behind her.

The body sits up. 'I'm not asleep. I just didn't want her to bother me. I'm Lynette."

I study her. She doesn't smile.

“I'm Julie. How long have you been here?" I ask as I put my clothes into the dresser.

"A few days."

"What did you do?"

"I took my mom's pills and she caught me and took me here. What did you do?" she asks as she moves to sit on the cold floor. 
I show her my wrists.

"What did you use?" she asks me.

"This one is from a razor blade. This one is from a kitchen knife. These two are from my keys. And the rest of them are from manicure scissors." I stroke each cut with my finger as I show her.

"Jesus. Who caught you?"

"My teachers saw."

"Why'd you do it?"

I sit down on the bed. "I wanted to feel."

She looks confused. "But didn't it hurt?"

"Yeah. But pain is feeling."

"Were you trying to die?"

I get down on the floor to sit closer to her. "Not at first. I really just wanted to feel. But then it stopped hurting and I was running out of space." I pull up my sleeves and show her my arms.

She uses her arms to lift her body off of the floor to move back a little.

I pull my sleeves back down. "Do you ever want to die?" I ask her.

"No," she answers without hesitation. "That's crazy."

"But why?"

"Because it is. Nobody just wants to die. Why do you want to die?"

I look down. I remember an afternoon when my dad comes home early from work, which never happens. He's whistling as he opens the door, so I get excited. I know he's in a good mood. 
"Go get dressed," he says cheerfully. "We're going out."

I run to go get dressed. I don't want to let him tell me twice. I go to my parents' room to show them I'm ready.

“Oh, where are we going?" I ask my dad.

He's not looking at me, but I can see his cheerfulness gone. His face is serious. He doesn't answer. I assume he didn't hear me.

I repeat, "Um, where are we going?"

He yells at me, "Just go put your shoes on before I hit you!"

I run to the front door and slip right into my sneakers.

I hear him mumbling, "Kids can't ask questions. They just listen.”

"What's the matter with you?" my mom asks him. "She's just asking where we're going. Why do you have to be so mean?"

"Shut up," he warns her.

I tense up, waiting for it. I wish for her to not say another word.

But nothing happens this time.

She quietly continues to get ready, but I know she's angry. I'm sitting on the couch, teary-eyed, shoes on, and silent.

I look back at Lynette. "The world is a bad place with bad people who do bad things."

"Ain't that the truth?" she laughs.

"I didn't notice that before." I point at the white cabinet in the corner. "Yeah, don't bother. I already did. It's locked." 
"Look at those." I point at the greasy finger streaks on it. "It looks like someone was trying to grab onto it while they're being dragged away or something."

Lynette laughs. "Would you be surprised? We're in a psychiatric ward."

I hear someone shout in the hall for us to wake up. He knocks loudly on each door as he passes by. It must be six.

We line up to brush our teeth. Then we line up for breakfast. We go into the Day Room to eat. I don't touch my food. I study my fellow patients. There's a girl singing and dancing and a few others are laughing at her. A boy teases her and they get into a fight. A couple of counselors come to pull them apart. They make them go into the hallway to stand facing the wall. Like a time-out in kindergarten. Except they are teenagers.

After breakfast, we go back to our rooms. A nurse comes to take my blood. She asks me why I am unhappy as a way to trigger small talk. I don't answer.

At eight, they announce that we're going to have a session of group therapy. Nick introduces himself as the counselor for this session. He says we're going to introduce ourselves and tell everyone why we're here.

He starts. "I'm Nick. And I'm here because I work here."

Some of us chuckle.

"Ashley, you're next."

"My name is Ashley. I'm fourteen years old. I'm here because I tried to stab my sister, because she made me mad, and she called the police and they put me here, and they said I have to learn how to work out my anger and aggression." 
“And how are you doing now? You've been here for three months. Do you feel improvement?"

"Yeah, I mean, I guess so. I haven't been that angry so far. Except for this morning." She glares at the boy who teased her at breakfast.

“Good. Julie?" Everybody looks at me now.

I look down at the floor. I remember a fight between my brother and sister. When Peter comes home from work, he asks Melanie if she finished doing what he asked her to do. But I can't remember what it was.

"No, I didn't have time," she answers as she's making me dinner.

"What the fuck?" he yells at her. "I ask you to do one thing and you can't even do it. You're so fucking useless. What have you even been doing all day?"

I don't like these voices, so I walk out of the kitchen, getting far enough away, but staying close enough, just in case.

"Peter, I went to school, and I've been cleaning the house since I got home. I'll do it later. It's not even important."

Peter mumbles more bad words.

“Julie, come eat dinner," Melanie calls for me.

“So do you have time now?" Peter demands.

"You know what? You don't have to be such a jerk," she says to him as she starts the dishes.

"What did you say to me?!"

I see him grab her hands from the running water and hold them over the stove. She screams and struggles, but he holds them still. I run to push him away and hug her. 
My mom comes out of her room, panicked. "What? What is it? What's going on?"

Now they say nothing.

My mom runs to me and wipes my forehead. "What is this?! Whose blood is this? What happened here?!"

I touch my forehead smearing the blood. I look at Melanie's hands. She puts them behind her back.

"It's nothing, Mom," she answers and walks away.

“Julie," Nick says again.

I don't move.

He moves on.

The boy next to me says, "My name is Alex. I'm here because I'm addicted to heroin. I'm learning how to channel my cravings in more productive activities."

We finish the circle.

Nick stands up. “Okay. Pamela is going to come in to conduct today's art activity."

"Hi, everyone. Today we are going to be writing letters. You're going to imagine that you are a grandparent in the future and you are going to write a letter to your grandchild to give them advice about life. Talk about some mistakes and regrets and what you want them to do differently. And when you're finished, you can draw a picture."

My future grandchild? What am I supposed to write? I watch everyone else getting started. I do want to write, but I don't know how to write this. 
I go up to Pamela. "Can we bring this stuff back to our room to work on?"

"No. You can't have art supplies in your room. You could hurt yourself."

"But I do want to write."

She has a confused look on her face. "Maybe that's enough for you for today. Go on to your room and settle down.”

Settle down. I didn't know I was out of control.

Maybe I ask the wrong questions. Maybe I say the wrong things.

Or maybe I'm just wrong.

I go back to my room to lie down. I remember when my brother, Steven, gets his driver's license. We go to the car dealership the same day. I am the world's most bored ten-year old. I walk around and count the cars. Then I walk around and admire the colors. And then I do it all again. I have enough fun, and I find my way back to my family and the car salesman.

He leans on a car and says to my brother, "I'm telling you, man, this is the one for you. My first car was very similar to it. It's a great car. It'll take you to school in the mornings and out with your friends at night. And then on Sundays, you can take your beautiful mom out." He winks at my mother.

She laughs and playfully hits his arm. She starts to ask a question, but my dad swoops in with a preemptive strike.

He whispers to her, "Let him talk to the boy, he understands better."

"I'm not stupid, I can talk too," she argues.

"You look like an idiot, shut up," he says through clenched teeth.

"Is something the matter?" the salesman asks. 
My dad chuckles and shakes his head.

Then he yells at my mom the whole drive home. "Do you even realize how inappropriate you were being? Next time, keep your mouth shut and let the right people speak."

We are the wrong people.

I don't know if I'm awake or asleep anymore.

Two people I don't know come into my room. They look young, but they are wearing lab coats, so I think they're important. One of them bends down next to my bed and puts her face close to mine.

"Hi, Julie. Guess what. My name is Julie, too." She smiles at me. "How are you feeling today?"

I don't answer.

I feel nervous, but I don't know why.

"Is it all right if I examine you?"

I hold myself and shake my head.

She doesn't listen. "It'll be quick, I promise," she says as she lifts up my shirt.

I forget the other one is in the room until I hear him laugh.

I want her to stop. I want them to leave. I want to push her away, but my body freezes still.

She continues to touch me. He continues to laugh.

I don't want to be here anymore. 
I remember the spring break when my family is desperate to distract me into being happy. They take me to Disney World. I get some stomach flu when we first get there. I can't stop throwing up. My mom panics and takes me to the emergency room. When the doctor comes in and asks what's wrong with me, my mom tells him in her broken English that my stomach hurts and that I've been throwing up.

He asks me, "Did you eat anything today? And when did this start?"

I don't say anything. I look away and try not to throw up again.

"Helloooo?" he says as he shines a light into my eyes.

He turns to my mom. "Does she speak English? Or is she just retarded?"

"No. No. She speaks."

"All right. Do you have anyone here who does speak English?"

My mom sighs in frustration.

The doctor shakes his head, writes a prescription, signs the discharge papers, and leaves.

"Why didn’t you say anything?" my mother asks me in Vietnamese. "Why didn’t you tell him how you're hurting?"

I turn away from her.

Julie pulls my shirt back down.

The psychiatrist comes into my room with a big smile.

“Hi, Julie. I'm Dr. Kim. I see you've met my students already. How are you feeling today?"

I don't answer. 
“They tell me that you hurt yourself. Can I see?" She rolls up my sleeves and examines my wrists, then makes marks on her clipboard. "Tell me: Why do you want to hurt yourself? You're not happy?"

I just look at her.

They tell me I'm here to protect me from myself. They tell me I'm here because it's wrong I want to die. They tell me I'm here because I should want to live. But they won't tell me why.

They won't let me write when writing is my vice.

They want me to speak, but they won't let me write when writing is my voice. They don't know that I don't really want to die.

I just want a cure.

I don't want to die from. I don't want to live with.

I just want a cure.

I want to ask Dr. Kim why she became a psychiatrist. I want to ask her why she's alive. I want to ask her if she's happy. I want to ask her if she has ever felt powerless. I want to ask her if she has ever wanted to die.

She just smiles. 
I want to know why she fucking smiles. I want to know what she believes in. I want to know why she chose this profession. I want to know if she's ever helped anyone. I want to know if she sleeps well at night.

“Okay, well, I'll come back to see you soon, when you feel like talking. Try to be happy. I'll call your parents to talk about starting you on Lexapro." She gets up to go.

It's morning again. But I don't know what day it is anymore. I ignore the hospital wake up call. I sleep all day. And they let me. By dinner time, I decide to line up for food. I take my tray and go back to my room. I sit on my bed and eat and stare out the barred window. It's just more bearable to look at than the four ugly, purple walls.

One of the counselors, Anna, opens my door abruptly. "What do you think you're doing?"

I just keep eating. I don't even look at her.

"You can't eat in here," she says sternly. "Go into the Day Room. You have to eat in the Day Room."

I continue to ignore her.

She gets angry. She grabs my wrist and starts to drag me out of the room. Her nails dig into one of my cuts. I drop my spoon into my soup.

"You don't want to follow the rules? Fine. You're going to the Quiet Room." 
The Quiet Room is uglier than my room. It has four padded walls. No windows. No tables. No chairs. No beds. Nothing.

"Pick a spot to stand. Or you can sit on the floor until your butt gets numb," she intimidates me.

"How long do I have to stay in here?"

"Until you calm down." She shuts and locks the door.

Because I am fucking out of control for wanting to be alone.

Because it is crazy to want to be alone.

So I sit.

I stand.

I pace.

Hours must be going by. Or time has slowed down to torture me.

I hear Nick's voice. "Where's Julie? Has anybody seen her?"

I hear him jingle keys until he finds the one to the Quiet Room.

"What did you do?" he asks me.

I'm still pacing. "Anna says I have to stay here until I calm down."

"It's okay. You can go get ready for bed."

I'm exhausted, but my body won't stop pacing. It's angry. I'm angry. Anna

doesn't like that I don't want to talk to anyone here, so that bitch put me in the Quiet Room.

“Stop, stop." Nick grabs my arms to get me to stop pacing.

His touch reminds me where I am.

I immediately apologize. 
"I'm sorry, I'm sorry."

I'm not sorry, though.

Dr. Kim comes back to see me today. She comes into my room smiling again. "Hi, Julie, are you feeling better today?"

I don't want to be here anymore.

No one can help me here. I don't understand why. They said they would help me. They said to trust them. Maybe they don't know how. Maybe they can't. Maybe they don't want to.

I start to smile at her. "Yes, Dr. Kim. I'm feeling much better today," I answer.

"Really? That's wonderful." She makes marks on her clipboard. "Maybe we don't have to put you on the medication after all. If you're still happy tomorrow, we can start to discharge you and you can go home." She leaves and closes the door.

I pick at my cuts. The scabs break. I bleed again.

I smear the blood into a smiley face on my arm.

Dr. Kim wants me to smile. She wants me to speak. She wants me to say that I'm happy.

I just want to go home now. 


\section{CHAPTER IV}

\section{INCUBATORS}

“Sleep, child, sleep away," Snake Girl rocked her baby in the hammock. Her son sped around his mother and baby sister with his underweight two-year old legs. He stopped spinning to run up to the woman once he caught a glimpse of her coming into the alley.

The woman came to touch the baby's cheek with her finger after she placed the groceries down.

“Can you watch them for a while?" Snake Girl asked. "Stephanie is already sleeping and Peter won't cause trouble."

"Are you going to go meet him again? For what? Are you going to at least tell him about your daughter this time?"

"I told you already, he told me to give him time to talk to his family about me."

“Child, listen to me. People like that, the people with money, they don't want anything to do with people like us."

"No. We are going to be a family."

"And what about Peter?"

Snake Girl looked at her firstborn. "He'll love him, too."

Snake Girl walked through the city to the place where they had met. She waited where he told her. She wondered if this was the day he would finally take her to meet his family, if this was the day he would become a father to her children. Or at least their 
daughter. She would have taken anything, anything if he had given it to her. She combed through her hair with her fingers while she glanced around for him.

When he came, he looked different. He didn't look her in the eye. He didn't even say much, just that he had to take her somewhere.

When they got to the hospital, he led her to a screaming newborn.

Snake Girl looked around at the gleam of the hospital and pictured the gloom of the alley where she gave birth to Peter and Stephanie.

"Take her home," he ordered.

"And do what? Raise her?"

"Her mother's dead. She bled too much while they were still taking the baby out."

Snake Girl's heart sunk into the pit of her stomach, not because she felt sorry for this woman and this child, but because she wanted to ask who this woman was, who this baby was. She wanted to ask the questions that she already knew the answers to. She wanted to ask the questions that she didn't want the answers to.

She looked at the wailing child and she felt her agony churn into pity. She picked her up, held the little life in her hands, and pretended she was hers.

But nights had gone by and the baby had never stopped crying. No matter what Snake Girl tried, she could not comfort this child. This child that wasn't hers. When morning came, she brought her back to him and apologized with her eyes. He didn't say much. He never did. He just made her go with him to hand the baby to his sister. He couldn't even touch it. This child that was his. 
Snake Girl wanted to ask him if he was grieving. If he loved her. The mother of the child. But she knew either answer would make her uneasy. So she handed over the baby and walked away. 


\section{CHAPTER V \\ WHEN NOTHING HAPPENED}

Nothing ever happened. Not in our house. My family's and mine.

It is Vietnamese custom to keep family business within family. "You can't trust anyone who doesn't share our blood," my aunt taught me. Even though I can't trust that crazy bitch for anything. She would kill for her blood. But she would also kill her blood. I would like to be honest. I would like to write the truth. But they would never forgive me. Maybe I can tell the truth after they die. Maybe death will be freedom from them. Freedom from the truth. But how will I ever forget? What if their ghosts never leave me? What if they haunt me every day? Maybe I can never escape them. Maybe death will be freedom for me. Freedom from memory.

When I was eight years old, my sister was eighteen years old. She was seeing someone. A man. That was enough of a crime in itself. But he was quite a bit older. 
Divorced. Had a child. And my sister was not the best student in school. This was her other crime. But she loved him. I saw that she loved him, because she did her best in school, got B's and C's, went out with him at night, on weekends, and took her punishment every time. She was never even sorry. And she never blamed anyone. She must have thought that this was the way things were, the way they were supposed to be. We all thought so. Because it was wrong to question to way things were.

But this time was a little different. She had left for the weekend. Later told me she enjoyed a getaway to Wisconsin Dells. And she came back Sunday morning and was opening the door, but the chain lock was up, so she was stuck. I was watching TV in the living room like I did every Sunday, so I got up to let her in, until my dad shouted. He came to let her in himself. But when the chain dropped, he grabbed her hair and shoved her onto the floor and dragged her into our home. I looked right at her eyes and she didn't even cry. She already knew it. We all knew it.

I always shut my eyes for the beatings. But I could never cover my ears hard enough. I'd push and I push and I push, but it'd be louder than I could push. It would echo from the inside of my ears.

We weren't allowed to leave the room. He always made us watch. Her lesson was our lesson. Just in case.

When I would open my eyes, I wouldn't watch her. I couldn't. I couldn't look at her. I couldn't even see her. I would watch him. I would study his face. And the images of him and his movements would be branded into my brain. 
He was so calm when he was punishing her. He was striking her, lecturing her, teaching her. But he was calm. It was his job. Our father. It was his role. He always told us how important it was to play our roles.

He finished. He told her to go take a shower to wake up. We all went back to our Sunday habits. But when she got out, he called us all back into the room. Of course it wasn't over. It was never over.

This time, she cried.

He had the scissors this time.

I remembered the last time. He told me to bring him the scissors. But I pretended I didn't hear him and ran away to hide.

He went to get them himself this time.

This time, I cried.

I thought this was it. He was really going to kill her. He was going to cut her, stab her, take her away.

So I screamed.

I sat in my mother's lap and I screamed so loud for her.

I wanted to go to her I wanted to go I wanted to get up I wanted to throw myself on her I wanted to protect her I wanted to I wanted to.

But my body wouldn't move.

Why wouldn't Mommy's body move? Why wasn't Mommy screaming? I knew why. We all knew why.

He cut off her hair and left it and left.

I realized that was why he wanted the scissors. 
We all went back to our Sunday habits again. He went to work. Took Steven and his toolbox and left. Off to fix someone else's house.

I thought it was over now.

I was watching TV again when she called for me. I thought I heard her the first time, but I wasn't sure. So my body still wouldn't move. But I heard her again, this time, for sure.

I went into the room that we shared, and I saw her sitting on the floor. Her eyes swollen. I had never seen them like that before.

I went to her and she held me. She was the only one who ever held me.

"Be good, okay? Don’t be like me."

I didn't understand.

So I went back to the TV, my only window.

My mom called me into the room she was napping in. I knelt down beside her.

She whispered to me, "Is he gone yet?"

"Yeah, he left right after."

"Go tell Peter to check on Melanie."

I got up to go, but she grabbed my ankle.

"But tell him not to tell her I said so."

I found Peter in the kitchen watching TV there. I whispered our mother's

command. And he obliged. So I went back to the TV because my task was completed.

Then I heard him scream.

“MELANIE MELANIE WAKE UP! MOM COME HERE FAST MOM SHE CUT HER WRIST MOM YOU HAVE TO COME MELANIE!" 
I saw my brother break from the room.

I saw my mother dart into the room.

I saw myself trance into the room.

Our room. My sister's and mine.

And I saw it.

Her eyes rolling to the back of her head.

Her arm holding out her wrist with all the life force she had left.

The bloody nail file on the desk. Our desk.

Blotches of blood all over our bed sheet, half hanging off the bed, like she grabbed it and pulled.

I never knew blood was that shade of red.

I dropped down in front of her and cried out for her, I tried to touch her, but my mother pushed me away. She wanted my sister for herself. She wouldn't let me touch her.

"WHY WHY WHY MELANIE WHY WOULD YOU DO THIS MY DAUGHTER WHY ARE YOU STUPID WHY WHY WHY WOULD YOU WHY?" she cried as she held and shook her.

My brother came back with the neighbors from the apartment downstairs. They were going to know. Peter was going to get in trouble. We were all going to.

They took her to the emergency room. I wasn't allowed to go. Before they stumbled out, I heard my mother speak out at my father for the first time, screeching into the phone.

"YOU DID THIS YOU KILLED HER YOU KILLED HER!" 
This was the first time I was ever left home alone.

I waited inside our room.

Then he picked me up. My father.

He drove to the hospital. I thought that if we were going to see her then she must be okay. I almost skipped in.

But my father pulled me back, and he whispered to me.

"Do you know why I cut her hair off today?"

I didn't answer. So he answered himself.

“Because she's so vain. She's too girly. She worries too much about her looks and she goes out all the time. But now if she feels ugly, she won't want to go out so much."

I felt my stomach flip.

When I was away at college, I was fucking around with my roommates one Friday night. Slouched on the couch, we were arguing about the color of blueberries. We couldn't agree and Christina threw one at Jaymarie and she threw a pillow back. I was searching for the facts on my phone when I saw Christina take out a nail file and point it at Jaymarie. They were still laughing.

But I saw it.

I saw the blood. 
The bed sheet.

The carpet.

Immaculate images in my mind.

I didn't hear myself screaming until Christina grabbed my arm and asked me what happened.

But I could only push my hands against my ears and shut my eyes.

I moved into the corner.

Shut down.

Drifted.

When I came back, they wouldn't stop asking me what happened and what was wrong. I managed to tell them that I just don't like nail files. Not those metal kinds. Because how could I tell them? It was not my story to tell.

It was a secret.

Sometime after they transferred her from the emergency room to the psychiatric ward, we went to visit her. In the car, I heard my dad try to care. Was he sorry? I don't know.

“The food must be really bad. Maybe they don't feed her enough. Do you have some candy in your purse? Maybe we can give her some."

"No! I already told you, they said we can't bring anything." 
"But maybe just a little piece of candy, just something sweet."

“I said no! It’s going to kill her! You just want to kill her!"

I watched his eyes watch the road through the rearview mirror. Our father. The teacher.

When she was finally allowed to come home, they told us that she would probably sleep a lot at first. They said she would spend a lot of time in bed. But not my sister. When we got home, she plugged in the vacuum cleaner and started to clean.

She started with our room.

But it was already cleaned.

Sometimes, I don't know what happened.

If it happened.

Sometimes, I can't remember.

Sometimes, I can't forget.

When I see her, I look for it. The scar on her wrist.

And then I know. 


\section{CHAPTER VI}

\section{EVACUATION}

"I'm going to America," she told him.

"How?"

“A policeman who's kind to me, he told me they're letting families of children of the American soldiers go, if we can file the paperwork and pay."

"So that black kid of yours is your ticket to America."

Snake Girl gulped the rest of her pride. "I just need some money for the papers.

He's not your son, but Stephanie and Melanie are your daughters. Please, just give me something, even a little bit is okay, to take them. And you'll never be bothered about us again."

"Fine. Meet me here tomorrow."

She waited at the same place in the morning. This time, with Stephanie and Melanie. She thought he should meet them, at least once.

But he never came. 


\section{CHAPTER VII \\ CHASING SHADOWS}

I sit at my desk facing the corner of our room doing the math homework that's not even due until next Thursday. I like the word problems. I like math when it's wordy.

Sam gave Jen $1 / 2$ of his jujubes. Jen ate $1 / 2$ of the jujubes and gave the rest to Kyle. Kyle kept 8 of the jujubes and gave the last 10 to Kim. How many jujubes did Jen eat? 18 .

Kathleen bought a sandwich for $\$ 6.45$, a bag of chips for $\$ 1.55$, and a drink for $\$ 1.15$. The tax was $\$ 0.75$. She gave the cashier $\$ 10.00$. How much change should Kathleen have received? $\$ 0.10$.

One of your friends is heading north for a holiday and the other friend is heading south. If their destinations are 1029 miles apart and one car is traveling at 45 miles per hour and the other car is traveling at 53 miles per hour, how many hours before the two cars pass each other? 10.5 hours.

I'm doing even more work to show my work to prove I didn't use a calculator when I swear I see, I feel a shadow behind me somewhere.

But I'm alone. I'm always home alone now. It's so cold here. Sometimes I sneak to turn the heat up just a little bit and rush to turn it back down when I hear keys clank at the front door. I get yelled at sometimes when the bill comes. I like when we have guests because they'll turn up the heat for them, and when the bill comes, there's still yelling, but not at me. 
I start to play the scenes from all the horror movies I'm not allowed to watch in my head. All the quiet scenes where you know something's bad about to happen just because it's quiet.

I seefeel the shadow again.

I close the textbook quietly. My thumb presses on Pearson. The book will be my secret weapon now, just in case. I seize it to my chest so hard, it hurts.

It's like going to see the doctor. When they hold the stethoscope to my chest, I feel like my ribs are just going to crumble and cave into me.

I examine the room. The shadow is trying to shrink to fit under the bed.

I'm scared to be scared. Every time Uncle catches me nervous or startled, he smacks the back of my head and reminds me, "This is our house. You have no reason to be scared in your own house."

I hear the shadow muttering. I recognize the mutters.

"Peter? Peter. What are you doing?"

“Quiet, quiet, they'll hear you!” He’s crouching down.

"What? Who? There's nobody home. What are you doing home?" I reach out to pull his arm and he flinches and shoves me.

"What did you do that for?!" I whine. "Stop this, it isn't funny."

"They're here, they're here, you have to lock the door." He's sweating now.

“Please, please stop. I'm scared." I'm crying now.

I don't know who this is.

I grab the phone and run into the bathroom and I lock the door. "Mom? I'm sorry. I'm scared. I don't know what to do. I'm sorry. Peter thinks someone else is 
here, but it's just me and him. I don't know. He won't tell me. I'm sorry. I don't want to. I'm sorry. Okay. Okay."

I unlock the bathroom door and peek out through the crack I make. He's mumbling, he's crying. When someone cries, there's something wrong, they could be hurt, I have to help. But I don't want to call the police.

"Peter?" I kneel down beside him. "Is someone bad coming? Should we call the poli-

"No!" He stands up now. "You can’t call the police! Do you understand me?!" He's bigger than me. He covers the light. Shadows made real.

"Never trust them okay? Do you hear me?" He grabs my arms and shakes me.

I wail. "I told Mommy already, I told her, let me go, she's coming home now she's coming and you'll have to stop, you'll have to!"

Now I know he's hurt. I've seen those eyes before. He lets me go and he darts out of the house faster than I can feel my arms again.

Peter's been gone for six weeks this time. I think he's been back when we weren't home though. My necklace is missing. I wonder how much white powder this one will get him. 
Mom borrowed some money from her friend to replace the necklace for me.

She's superstitious like that. She thinks Buddha hanging on my neck will protect me. What does she think I need protection from?

She's quieter when Peter's gone. Except when she's in one of her moods.

I sit and work on the extra homework she made Stephanie give me when I hear boxes being torn and profanity being muttered. I jump at the noises and run to them, a habit I've learned from living in this house.

She's at it again. Sifting through Peter's things to throw them away as she swears that Buddha must have been punishing her for making her his mother.

I wonder where Peter is. I wonder what Peter would be like if his father was around. I wonder what would be different if Peter and I had different mothers also.

Sometimes he cries and tells me I'm lucky to have a father. I don't know if I'm lucky to have my father. I wonder if I would be like Peter if my father had died when I was a baby. I wonder if I would be looking for white powder too.

Later, I see Mom go out to the dumpster and bring Peter's things back to patch together and put away. When she finishes, she comes to hug me and cry.

"I didn't have a choice, I just didn't have a choice." She cries on me.

"What happened, Mommy?"

“He's like this because of me. He's addicted because of me. I wasn't there for him. I sent him away."

"But why?"

"Your father. He wouldn't stop. He wouldn't stop beating him. And then he told me. He told me it was him or my son. I had to, I had to. You needed your father. 
Peter's father died and he would cry to me all the time and ask me why other kids got to have a father and he didn't. I just didn't want you to have that pain.” She sobs now.

I move away from her.

I think about all of the times I've heard the sounds of Daddy's fists on Peter's body.

I think about all of the times I've heard the sounds of Daddy's fists on Mommy's body.

And Melanie's.

And Stephanie's.

And Steven's.

I remember when Mom made Peter go to work with Dad. Peter told her he was scared, but she told him Dad loved him and would love him even more if he helped. I had a half day of school and Mom had to work, so I went to work with Dad and Peter. I sat quietly and watched Peter focus and mutter what each tool could do. I could tell he just didn't want to be wrong.

But he was already wrong.

He was the wrong child.

Dad was the wrong father.

Dad was on a ladder and when we saw it wobble, Peter ran over to stabilize it. He said, "Let me hold that for you, Dad." And Dad yelled at him in Vietnamese, "Shut up, boy. I'm not your fucking father."

I remember Peter leaving for three months that time. 
I want to ask Mom why I've never heard the sounds of his fists on my body. I want to ask her why I'm the lucky one. I want to ask her if she thinks my brothers and sisters hate me.

But I don't ask her.

I hate Sunday night grocery shopping. I have to carry things in the store or I have to wait in the car. Melanie and I park in the alley to wait for Mom. I know the shadow that's crouched down by the dumpster.

“Melanie?” I whisper because I don't even know if I want her to hear me. "Um, Melanie?" I speak up a little and point.

She looks up, sees our brother, and whips the door wide open. "Peter? Peter. Peter! Come home, come on, get in the car and come home. It's been too long, it's getting cold now, please, please, Mom's not mad anymore, I swear, right, Julie?" I just look at him.

Melanie is still pleading, "Peter, Mom's not mad, you can come home." He stands up and just stares at us.

I don't know what these eyes say.

I see Mom come out rustling the foods we'll eat this week. Peter sees me see her, sees her, runs.

Melanie screams pleading screams I haven't heard yet. 
I didn't know Peter could run that fast.

Why is he so scared?

Is he scared of us?

I wish I could know where he stays when he doesn't come home.

The prison guard chews gum with her mouth open. I've been told that's rude. She takes Mom's purse, all of our jackets and shoes. She runs her hands in, around, through them and hands them back. She says we have to wait while they bring him into the visitation room.

"Can I go to the bathroom, please?" I ask Mom. She gets up to go with me as she always does.

"Um, you can't go with her. It's not allowed." The guard puts her arm out and her arm is louder than her voice. "She has to go alone. I have to check her again first. Come here."

She takes my shoes, makes me take off my belt before she runs her hands in, around, through me. I want to cry. But I don't know why. It doesn't hurt.

But it does.

“Okay, the bathroom's over there." She points.

I look at my feet.

Then at her. 
"You can't wear shoes in there."

I go to the bathroom and I wonder if Peter's feet get cold in here. I wonder if he gets goose bumps like I do. If he trembles. If his teeth chatter.

They tell us Peter is ready and lead us to the room. When we walk in, I see him smile for a second. And then Melanie screams cries as she runs to slam her hands on the screen.

There's a little rusty speaking hole in the screen. It looks like the top of a microphone. Where's the telephone you hold like in the movies?

Mom screams cries now, too, but not the same cries that Melanie is screaming. I hear words she's reserved strictly for Peter.

Bastard child.

Demon.

Son of a bitch.

Ungrateful.

Disgrace.

He's going to be the death of her.

I wonder if Mom hates Peter the way she screams. She's the one that sent him away when Dad told her to. But she tells me it's not her fault. She tells me that if she didn't, then Dad would have left and I wouldn't have a father either. I wonder if Peter's father was nice.

Are soldiers nice?

I wonder if Peter's greater crime is that he didn't come from my father or that his father was black. 
I see Peter hang his head.

I know he's ashamed. I know he wants to die. I know he thinks he deserves to die. I know he wants to be with his dad. I've seen these eyes before. I know what they say.

Peter's been limping for three days now, wearing the same jeans. I ask him why, but he shrugs me off. But he falls down and cries, so Melanie pulls his pant leg up. Then she cries, and I look. It looks like part of his flesh was sliced or burned off.

“Don't tell Mom, don't, don't tell her," he pleads through groans.

"But how? What did you do?" Melanie asks him.

"I don't remember, okay?"

"God, Peter, you were fucking high again!" Melanie yells as she studies the wound.

"Just shut up and get me some bandages."

"No, you have to go to the hospital." Melanie grabs her keys.

When we help him into the car, I hear him make promises he's already broken a thousand times. I hear him say he's sorry. At least he's sorry. Now we count until the next time. 


\section{CHAPTER VIII}

\section{CITIZENSHIP}

I help Mom study every day when she gets home from work. When I hear her keys, I run to get the flashcards we made and shuffle them as well as I can. She comes in

and puts down her things as I climb onto the counter to sit. She starts making dinner and tells me she's ready to begin.

"What do we call the first ten amendments to the Constitution?"

"The Bill of Rights."

"Correct. How many stripes are the American flag?"

"Thirteen."

"Do you remember what they stand for?"

"The colonies."

I laugh at the way she pronounces colonies.

She repeats the word four more times until I nod my head.

"What are the three branches of government?"

"Executive, Legislative, Judicial."

I laugh again.

"I'm wrong?" she asks me.

"No, but you say those words better than you can say the other word."

“It's because I'm uneducated. So you have to go to school and get good grades and be better than me, okay?" 
"Why do you have to take this test?" I ask her.

"So I can become American like you."

"But we're Vietnamese."

"No. We live in America. This is our home."

"Will you ever take me to see where you were born?"

"No. That's my past now," she speaks softly.

“They say I'm not American.”

"Who does?"

"The people at school."

"I don't want you to speak Vietnamese anymore. You need to speak English all of the time.

I shuffle the cards.

"So you can be as American as they are." 


\section{CHAPTER IX \\ LIVING WITH DYING FROM}

2011

“But I know I'm not crazy."

2013

The sickness takes me.

It transforms me, giving me invincibility at first.

All of my senses are suddenly intensified and I can feel everything.

I feel the lights. They soak into my pores and become a part of me. They tickle my nerves and steer me.

I follow.

I know I should slow down, but I can't.

I want to go everywhere I want to do everything I can't stop moving can't stop laughing can't stop anything because I can do everything.

Nobody can stop me because I can't hear them.

I hear only the sickness. 
It tells me to run to the top of the hill, blanketed with snow and ice, and roll down. I roll. It tells me to run across the busy street because it'll carry me between the cars. I run. It tells me to jump into the lake. I jump.

I love the sickness because it makes me feel alive.

Until it transforms me again.

It makes me mortal now, separating my body from me.

The body is no longer my own. I forget how to use it. I can't get the lungs to work. I can't control the nerves. The sickness tells me to steer now, but it won't tell me where to go.

I can't breathe. I. can't. breathe. CAN'T. BREATHE. C-C-C-C-C-C-C-C-C-C-AN'T. Suck in air to blow out, but it doesn't flow past the throat. Try again try again. Hold head. Hold for steady. Focus. Suck in air. Why won't it come out?

Cry. Maybe air will sneak out with tears. Cry loud. Still can't breathe.

Feel the lights still. But they singe into the skin now.

Close the lights. Close the eyes.

Grab the arms. Hug the body. Hug for steady.

Stop shaking. It's okay it's okay.

Look around at nothing happening. Look around at the quiet. 
It's just the sickness. It's just inside.

Still not breathing. Still crying. Still shaking.

Grab the wrist. Grab keys.

Saw.

See vein. See blood. See real.

Intubation. Breathe.

Heart slows. Sickness releases. Mind quiets.

I hear silence. I see air. I feel gravity.

Lie down for days.

2003

"I don't know what's happening to me."

2004

"I don't know why this is happening to me."

2007

I'm crybegging in the office. "Please please don't tell my parents please I'll stop I'll make it stop I swear please please."

"No, Julie. You need help. We're going to make sure you find it this time." 
When Mom comes in, her face is so white, she blends in, and I almost don't recognize her.

"Are you mad at me? What did I do? What did I do? Please tell me. Tell me how to make you happy," she says after the social worker rolls up my sleeves.

It's only my sleeves, but I feel naked.

They tell us I have to go back to the hospital.

I squeeze my hands together hard and crybeg louder. 'No no no no please you can't you can't I'll be good I promise I promise I'll stop I'll stop don't send me back don't send me please I'm sorry I'm sorry I'm sorry I'm sorry I won't do it anymore I won't." "I'm sorry, Julie, you have to. You're sick. I want you to get better." I run.

I make it down all of the staircases and I fall down the last steps because the sickness has my legs now.

I hear the social worker screaming my name as she runs after me. "I don’t want to please please please please," I sob hysterically. "You have to, you have to go to the hospital now." My left hand grabs the spindles. "You don't know you don't know you don't know what they do." My right fist pounds into the floor.

Mom runs down the stairs to us and grabs both of the social worker's hands as she gets on her knees. 
"Please please don't take her again please please I beg you." She's crybegging now.

Dad comes next to me now, shaking fists shouting, "WHY ARE YOU DOING THIS, LOOK AT WHAT YOU'RE DOING, LOOK AT YOUR MOTHER, YOU'RE AN EMBARRASSMENT, YOU'RE MAKING YOUR MOTHER SUFFER, THIS IS YOU AND YOUR SELFISHNESS.”

The social worker makes a phone call.

She turns towards Mom. "Mrs. Tran, do you have insurance?"

Mom ignores her. She stands up and faces me now. "Do you see?" she asks. "You're not even at the hospital yet and they're asking about insurance. They don't care about you. They just want money. That's all they care about. Tell them. Tell them you're okay so you don't have to go."

2013

"Is everything all right?"

“I can feel it. It's starting now. I can't breathe I can't breathe." I panicpace.

"Here, have a seat."

I sit and hold the arms. I hug the body as it shifts back and forth. I suck in air to blow out, but nothing.

"I hate these lights." I shut the eyes.

"Do you want to go to counseling services?"

"I told you already, no." 
"It could be different this time."

"Stop."

"Trust me. There are good people there. And you're not a kid anymore." "Stop. Please."

"I'm just saying that you would have more say in what kind of treatment you get this time."

"No. I will never trust one of those people ever again."

2008

"Do you have anything that you're passionate about? Anything you get excited about?"

"I want to be a teacher."

"Maybe you should try to want to stay alive. Maybe we should set that as a goal."

"I never said I want to die."

"Then why are you doing things like this?" She picks up the empty bottle of pills.

"To make it stop."

2004

"Are you having a bad day?"

"I'm having a normal day."

"Did something happen today?"

"No."

"Is there something you feel guilty about?"

"Yes." 
"Did you do something bad?"

"I don’t know."

"Why do you do this?"

"I don't deserve to live."

"Are you kidding me? Who told you that?"

"The sickness."

2005

"Yes, we need an ambulance. We stopped the bleeding for now. Some are minor, borderline artificial. Okay, thanks." The counselor hangs up and turns to me and smiles.

"What does artificial mean?"

"That you were hesitant."

2012

"I already told you I don't want to die."

"Then why would you hurt yourself?"

"To stay alive."

2011

"How could you ever want to die? That's crazy."

"It's not that."

"Then why are you saying these things? You're scaring me."

"It's the sickness." 
"What do you mean?"

“It just won’t let me go."

Crazy.

Deranged.

Mad.

Insane.

Demented.

Unhinged.

Unstable.

Senseless.

2009

"Tell me how it hurts."

"It's piercing. It's merciless."

"But you know nothing is happening right now, right?"

"It's inside."

"Where?"

"Forget it."

"Why?"

“You don't even believe me."

"I do."

"How could you believe this?" 
"I'm just trying to understand."

"I'm not crazy, I swear."

"I didn’t say you were."

"I know it sounds crazy to you."

2006

“They tell me that you hurt yourself. Can I see?" She rolls up my sleeves and examines my wrists, then makes marks on her clipboard. "Tell me: Why do you want to hurt yourself? You're not happy?"

I just look at her. They tell me I'm here to protect me from myself. They tell me I'm here because it's wrong I want to die. They tell me I'm here because I should want to live.

But they won't tell me why.

And they won't let me write when writing is my vice. They want me to speak, but they won't let me write when writing is my voice.

They don't know I don't want to die.

I just want a cure.

I don't want to die from. 
And I don't want to live with.

I just want a cure.

I want to ask Dr. Kim why she became a psychiatrist.

I want to ask her why she's alive.

I want to ask her if she's happy.

I want to ask her if she has ever felt powerless.

I want to ask her if she has ever wanted to die.

She just smiles.

I want to know why she fucking smiles.

I want to know what she believes in.

I want to know why she chose this profession.

I want to know if she's ever helped anyone.

I want to know if she sleeps well at night.

“Okay, well, I'll come back to see you soon, when you feel like talking. Try to be happy.

I'll call your parents to talk about starting you on Lexapro.”

Lexapro.

Treatment

Antidepressant. 
Serotonin booster.

Happy pill.

Sickness.

Clinical depression.

Bipolar disorder.

Suicidal tendencies.

Quiet.

Antisocial.

Refuses to participate.

Sleeps a lot.

Writing utensils not allowed in room.

At Chicago Lakeshore Hospital, your name is your affliction.

2014

At ISU Student Counseling Services, they evaluate you first from the answers you give on a questionnaire.

"I feel like my family loves me," reads the first question.

I have to choose a number.

"I swore I would never talk to another mental health professional for as long as I live." "Then why are you here?" 
"A last resort."

"Are you planning on killing yourself?"

"Do you think you can help me?"

"I want to try. Tell me what brought you in today, especially after all of these years."

"Apathy. I usually feel extremes. Euphoria or pain. Intense senses. Now I feel

nothing."

"Have you ever felt this way before?"

"Once. When I was thirteen."

"How did it stop?"

"They put me in the hospital."

"Did they put you on medication?"

"It wasn't the medication."

"What do you think it was?"

"I don't want to talk about that anymore."

"Okay."

"Do you have any questions for me right now?"

"Why is it wrong to want to die? Why is it so crazy to want to die? If someone is in so much pain that death could release them from, why is it not their right to choose to choose?"

"I don't know if I can answer that."

"But you have power over me in here."

"How do you mean?" 
"If I say the wrong thing, you'll make the call, you'll get the papers, and you'll lock me up. Because you can't understand."

"Well, that is true. But our first concern here has to be safety."

"Safety. Or you'll get in trouble."

“Or you'll hurt yourself."

"What about people who engage in risky activities? Nobody has the right to try to stop them from potentially hurting themselves."

"That's different. You're actually intending to hurt yourself."

Intent.

Mens rea.

Crime.

2005

My mom is pleading with the monk. "I think it's demons. She's so haunted these days. This never happened before. She's just very unhappy. Can you help us? Can you stop the demons?"

The monk closes his eyes and meditates for a moment.

I sit and daydream about every horror film with exorcisms.

He sends us home with Buddhist literature and music. 
My mom makes me read it. Stories of enlightenment, nirvana, reincarnation.

She plays the music when I sleep. Gentle chanting in a foreign language.

2014

'I used to write to remember. But some things I don't want to remember anymore.

Some things I can't forget. And they replay in my head perfectly. But they happened so long ago, how is it even possible? I want them to make sense because maybe then I can make them stop. But they don't."

I see images all the time now.

I hear screams all the time now.

I feel pain all the time now.

And I can't make it stop.

2011

"Why are you crying? Stop crying. We have to go home now."

"No no Steven we have to go to Melanie we have to help her we have to." I'm sobbing. "What are you talking about? What's wrong with Melanie?"

"He's hurting her he's hurting her he's hurting her we have to stop him." 
“Oh my god, Julie. You're such a fucking kid. That was a long time ago. Let it go already."

"No no you don't understand. Her husband hits her now. We have to go we have to save her."

"How would you know? You don't live with them. And if Melanie wants to let her husband hit her, that's their business, Julie, who the fuck cares?"

"You don't understand you don't understand. We have to help Mom. She's tired. She's so tired. I don't want her to suffer anymore."

"What the hell are you talking about now? Mom's at home sleeping. She's fine."

"No no no she's not fine! You don't see it you don't see."

"This is why you're not supposed to drink when you're young and stupid."

"We have to protect her we have to try please please help me."

"You seriously have a problem."

"I just want it to stop. I want it to stop."

2000

"YOU DID THIS YOU KILLED HER YOU KILLED HER!!!”

2015

"I hate him I hate him I hate him I hate him I hate him I hate him I hate him I hate him."

I cry. I pound my fists into the floor.

"Julie, it's okay. Just take a deep breath. You've had a lot to drink." 
"Just make it stop just make it stop please please I'm sorry I'm sorry." I pound my fists into my head now. "I hate him I hate him so much I hate him."

"He's not here. He's not here right now, okay? It's just you and me. It's going to be okay." George shushes me and takes my hands.

"It hurts. It hurts so much," I sob.

"I know. I'm so sorry, baby, I'm so sorry." He presses his forehead on mine.

2008

"I think it's not going to stop until it kills me." 


\section{CHAPTER X}

\section{TOO AMERICAN}

I wait in the car for Dad. He's taking me to Union Station so I can catch my train back to Normal. I wanted to take the CTA, but he insisted. And Dad's used to getting his way.

I'm anxious and hyperaware. I try not to breathe too loudly.

I forget how to breathe altogether.

I close my eyes and try to sleep so that he won't talk to me.

But that doesn't stop him.

"I don’t like you seeing George."

I open my eyes and inhale.

He continues, 'I'm not saying he's a bad person. And I'm not saying you should date someone who's Vietnamese. But you know my English isn't that good. You should be with someone I can speak with. And someone who will uphold our Vietnamese customs."

I don't exhale.

I look at the street signs and wish for us to get to Union Station faster.

He goes on, "Your Vietnamese is already really weak. And you're the youngest, so it's like you're the farthest from me and your mother. Sometimes, I don't even know where you get your values from. I'm really worried you're becoming too American." I say nothing. 
I read on the train.

At one of the stops, a stranger boards the train and sits down next to me.

He looks at my book and asks, "Are you a student?"

I smile and nod.

"Where do you go to school?"

"Illinois State University."

"What do you study there?"

"English."

“Oh, do you enjoy studying here?"

I raise an eyebrow. "Yes, I do," I answer.

"Well, how long have you been in America?"

I let out a chuckle. "I was actually born in America."

He looks shocked. "Oh, well, where are you from?"

I stop smiling. "My parents are from Vietnam."

“Oh, well, there you go.” He looks satisfied now.

I look at my arm. I look at the color of my skin. I look at his. And I know that I will never be as satisfied or American as he is.

That's my future now. 


\section{REFERENCES}

Bernstein, Charles. The Politics of Poetic Form: Poetry and Public Policy. New York: Segue Foundation, 1989. Print.

Boully, Jenny. The Body: An Essay. Athens: Essay Press, 2007. Print.

Burton, Robert. The Anatomy of Melancholy. Kila: Kessinger Publishing Company, 1857. Print.

Caruth, Cathy. Trauma: Explorations in Memory. Baltimore: The Johns Hopkins University Press, 1995. Print.

Chau, Angie. Quiet As They Come. Brooklyn: Ig Publishing, 2010. Print.

Cheung, King-Kok. Articulate Silences: Hisaye Yamamoto, Maxine Hong Kingston, Joy Kogawa. Ithaca: Cornell University Press, 1993. Print.

Cho, Margaret. I'm the One that I Want. New York: Ballantine Books, 2001. Print.

Chua, Amy. Battle Hymn of the Tiger Mother. New York: The Penguin Press, 2011. Print.

Chua, Amy, and Rubenfeld, Jed. The Triple Package: How Three Unlikely Traits Explain the Rise and Fall of Cultural Groups in America. New York: The Penguin Press, 2014. Print.

De Veaux, Alexis. Yabo. Washington, DC: Redbone Press, 2014. Print.

Derrida, Jacques. Voice and Phenomenon: Introduction to the Problem of the Sign in Husserl's Phenomenology. Evanston: Northwestern University Press, 2011. Print.

Duncan, Patti. Tell This Silence: Asian American Women Writers and the Politics of Speech. Iowa City: University of Iowa Press, 2004. Print.

Foucault, Michel. The Birth of the Clinic: An Archaeology of Medical Perception. New York: Vintage Books, 1994. Print.

Foucault, Michel. Madness and Civilization: A History of Insanity in the Age of Reason. New York: Random House, 1988. Print. 
Frame, Janet. Scented Gardens for the Blind. New York: George Braziller, 1980. Print.

Gilman, Charlotte Perkins. The Yellow Wallpaper. New York: Bedford Books, 1998. Print.

Herman, Judith. Trauma and Recovery: The Aftermath of Violence - from Domestic Abuse to Political Terror. New York: Basic Books, 1997. Print.

Johnson, Kent. Doubled Flowering: From the Notebooks of Araki Yasusada. New York: Roof Books, 1997. Print.

Kane, Sarah. 4.48 Psychosis. London: Methuen, 2000. Print.

Kapil, Bhanu. Humanimal. Berkeley: Kelsey Street Press, 2009. Print.

Kapil, Bhanu. Interview by Andy Fitch. "Andy Fitch with Bhanu Kapil." The Conversant. 2013. Web. 2 Jan 2015.

Kapil, Bhanu. Interview by Stephanie Luczajko. "An Interview with Bhanu Kapil.” TINGE Magazine. Fall 2012. Web. 2 Jan 2015.

Kapil, Bhanu. Schizophrene. Callicoon: Nightboat Books, 2011. Print.

Kingston, Maxine Hong. The Woman Warrior: Memoirs of a Girlhood among Ghosts. New York: Vintage International, 1989. Print.

LaCapra, Dominick. Representing the Holocaust. Ithaca: Cornell University Press, 1994. Print.

LaCapra, Dominick. Writing History Writing Trauma. Baltimore: Johns Hopkins University Press, 2014. Print.

Lahiri, Jhumpa. Unaccustomed Earth. New York: Vintage Books, 2008. Print.

Leys, Ruth. Trauma: A Genealogy. Chicago: University of Chicago Press, 2010. Print.

Lowe, Lisa. Immigrant Acts: On Asian American Cultural Politics. Durham: Duke University Press, 1996. Print.

McKeown, Adam. Melancholy Order: Asian Migration and the Globalization of Borders. New York: Columbia University Press, 2008. Print.

Minghella, Anthony, and Ondaatje, Michael. The English Patient: A Screenplay. New York: Hyperion Miramax Books, 1996. Print. 
Morris, Rosalind. Can the Subaltern Speak?: Reflections on the History of an Idea. New York: Columbia University Press, 2010. Print.

Nelson, Cary, and Grossberg, Lawrence. Marxism and the Interpretation of Culture. Urbana: University of Illinois Press, 1988. Print.

Okada, John. No-No Boy. Seattle: University of Washington Press, 1977.

Ong, Aihwa. Buddha Is Hiding: Refugees, Citizenship, The New America. Berkeley: University of California Press, 2003. Print.

Ong, Aihwa. Flexible Citizenship: The Cultural Logics of Transnationality. Durham: Duke University Press, 1999. Print.

Ovid. Metamorphoses. Trans. Charles Martin. New York: W. W. Norton \& Company, 2004. Print.

Palumbo-Liu, David. Asian/American: Historical Crossings of a Racial Frontier. Stanford: Stanford Univerity Press, 1999. Print.

Rankine, Claudia. Interview by Robert Caspar and Jennifer Flescher. "Interview with Claudia Rankine." jubilat, Number 12. July 2006. Web. 2 Jan 2015.

Said, Edward. Culture and Imperialism. New York: Vintage Books, 1993. Print.

Said, Edward. Orientalism. New York: Vintage Books, 1979. Print.

Sartre, Jean-Paul. Literature and Existentialism. Secaucus: The Citadel Press, 1949. Print.

Saunders, Rebecca. The Concept of the Foreign. Lanham: Lexington Books, 2003. Print.

Saunders, Rebecca. Lamentation and Modernity in Literature, Philosophy, and Culture. New York: Palgrave Macmillan, 2007. Print.

Scarry, Elaine. The Body in Pain: The Making and Unmaking of the World. New York: Oxford University Press, 1985. Print.

Virgil. The Aeneid. Trans. Allen Mandelbaum. Berkeley: University of California Press, 1971. Print.

Wah, Fred. Diamond Grill. Edmonton: NeWest Press, 2006. Print.

Yamamoto, Hisaye. Seventeen Syllables. New Brunswick: Rutgers University Press, 2001. Print.

Yun, Mia. House of the Winds. Brooklyn: Interlink Books, 1998. Print. 